\title{
A CHECKLIST OF ACRIDIDAE (ORTHOPTERA: ACRIDOIDEA) FROM HARYANA, INDIA
}

\author{
HIRDESH KUMAR* \& MOHD KAMIL USMANI
}

\author{
Section of Entomology, Department of Zoology, Aligarh Muslim University, Aligarh 202002 \\ <entomologist1985@gmail.com>*; <usmanikamil94@gmail.com> \\ Recibido: 30/09/2014; aceptado: 13/02/2015
}

\begin{abstract}
Kumar, H. \& Usmani, M. K. 2015. A checklist of Acrididae (Orthoptera: Acridoidea) from Haryana, India. Acta Zoológica Mexicana (n. s.), 31(2): 234-238.
\end{abstract}

\begin{abstract}
A survey of Acridid fauna in totally different habitats in different regions of Haryana state was carried out during the period from 2009 to 2011. Thirty six species were captured belonging to twenty three genera and eight subfamilies. Oedipodinae (28\%) was the most dominant subfamily. Spathosternum prasiniferum prasiniferum (Walker, 1871) was found to be most abundant.

Key words: Acrididae, Haryana, Grasshoppers, Locusts, India.
\end{abstract}

\section{INTRODUCTION}

Acrididae is a family of grasshoppers including locusts in the superfamily Acridoidea which belongs to the order Orthoptera. Superfamily Acridoidea has shown maximum diversity and divided into eleven families of which Acrididae is widely distributed in India. Locusts and grasshoppers constitute an economically important group of orthopteran pests that infest a number of cultivated and non-cultivated crops. The distribution pattern of grasshoppers is changing rapidly due to the encroachment of grasslands and forests for agricultural and industrial purposes. Kirby (1914), Uvarov (1927), Henry (1940), Tandon \& Shishodia (1969, 1976a, 1976b, 1976c, 1977), Bhowmik (1985), Shishodia \& Mandal (1990), Usmani \& Shafee (1990), Shrinivasan \& Muralirangan (1992), Hazra et al. (1993), Shishodia (1997, 1999, 2000, 2008), Shishodia \& Tandon (2000), Priya \& Narendran (2003), Shishodia et al.(2003), Kulkarni \& Shishodia (2004), Thakur et al. (2004), Ingrisch et al. (2004), Shishodia \& Dey (2006, 2007), Saini \& Mehta (2007), Chandra et al. (2007, 2010), Shishodia \& Gupta (2009), Usmani et al. (2010), Senthilkumar (2010) and Kumar \& Usmani (2012a, 2012b) have contributed to the taxonomy of Indian Acridids. There are only few sporadic reports or papers available on acridid fauna of Haryana. Shishodia et al. (2010) reported 30 species over 25 genera belonging to four families of order Orthoptera from this state. So, keeping in mind the importance of these pests in agriculture, an extensive and intensive survey was made to find out the distribution and diversity of these pests at different habitats in various localities in this area.
Kumar, H. \& Usmani, M. K. 2015. Lista comentada de Acrididae (Orthoptera: Acridoidea) de Haryana, India. Acta Zoológica Mexicana (n. s.), 31(2): 234-238.

RESUMEN. Un estudio de la fauna de acrídidos en diferentes hábitats y regiones del estado de Haryana se llevó a cabo durante el período comprendido entre 2009 y 2011. Treinta y seis especies fueron colectadas pertenecientes a veintitrés géneros y ocho subfamilias. Oedipodinae (28\%) fue la subfamilia más dominante. Spathosternum prasiniferum prasiniferum (Walker, 1871) es la especie más abundante.

Palabras clave: Acrididae, Haryana, saltamontes, langostas, India.

\section{MATERIALS AND METHODS}

Haryana (Fig. 1) is a part of Kuru region in North India, bordered by Punjab and Himachal Pradesh to the north, and by Rajasthan to the west and south. The river Yamuna defines its eastern border with Uttarakhand and Uttar Pradesh. Haryana is located between $27^{\circ} 39^{\prime}$ to $30^{\circ} 35^{\prime} \mathrm{N}$ latitude and between $74^{\circ} 28^{\prime}$ and $77^{\circ} 36^{\prime}$ E longitude. The altitude of Haryana varies between 700 and $3600 \mathrm{ft}$ (200 metres to 1200 metres) above sea level. The total area of the state of Haryana is 44,212 square kilometres. An area of $1,553 \mathrm{~km} 2$ is covered by forest.

The adult grasshoppers of both sexes were collected from various localities of Haryana during the period of 2009 to 2011 which served the basis for the present critical study. They were caught by hand, by forceps, and by the ordinary aerial insect net. The net was used for catching insects individually or by sweeping on grasses, bushes and other vegetation. The specimens were first relaxed, stretched and later, they were pinned and labeled. Identification of species is based on both morphological and genital characters. The collected materials by the author during survey are deposited in the Zoological Museum of the Aligarh Muslim University, Aligarh, India.

\section{RESULTS}

The material collected from different area and various localities of Haryana state includes 430 specimens of acridids. This collection includes thirty six species belonging to twenty three genera and eight subfamilies (Table 1). Spathosternum prasiniferum prasiniferum (Walker, 


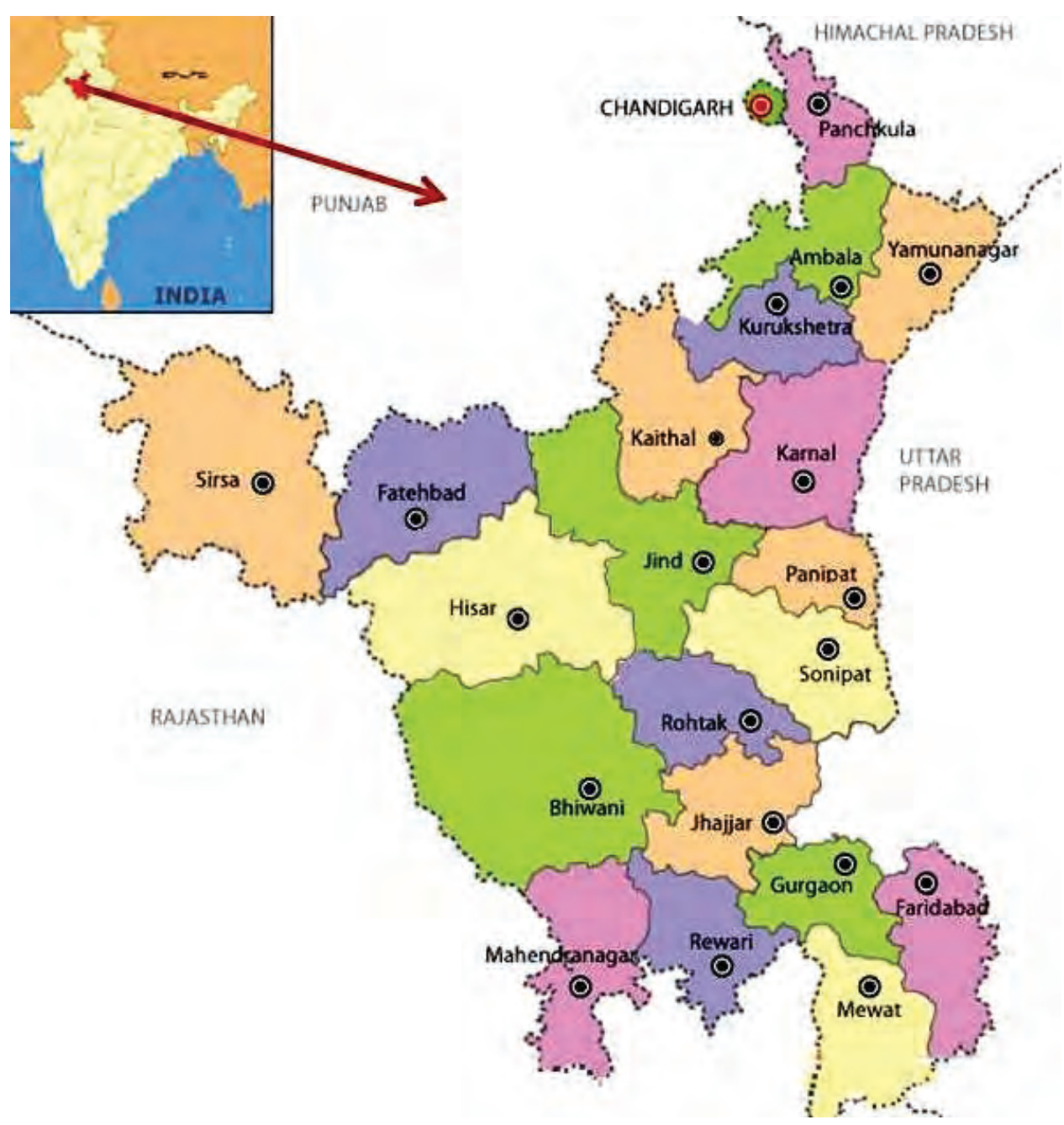

Figure 1. District map of Haryana, India.

1871) was collected in the maximum number. The members of subfamily Oedipodinae with 28\% (Fig. 2) are the more diverse and abundant species. Some abundant species of Oedipodinae are Trilophidia annulata (Thunberg, 1815), Aiolopus simulatrix simulatrix (Walker, 1870) and Aiolopus thalassinus thalassinus (Fabricius, 1781). The following species Oxya hyla hyla (Serville, 1831), Spathosternum prasiniferum prasiniferum (Walker, 1871), Hieroglyphus nigrorepletus (Bolivar, 1912), Hieroglyphus banian (Fabricius, 1798), Trilophidia annulata (Thunberg, 1815), Aiolopus simulatrix simulatrix (Walker, 1870) and Acrida exaltata (Walker, 1859) are found in almost all habitats. Twenty six species and eleven genera are reported for the first time from this state.

\section{DISCUSSION}

Acridids popularly known as locusts and grasshoppers are major pests of various agricultural crops and grass- lands. Their destructiveness is well known throughout the world. Locusts are the key pests of agricultural land of those countries which are bordered by the deserts. Shishodia et al. (2010) and Chandra et al. (2010) reported 15 species under 15 genera belonging to seven subfamilies of Acrididae from Haryana. A few species such as Cyrtacanthacris tatarica tatarica (Linnaeus, 1758), Schistocerca gregaria (Forskal, 1775), Tylotropidius varicornis (Walker, 1870), Aulacobothrus socius Bolivar, 1902 and Tristria pulvinata (Uvarov, 1921) reported by Shishodia et al. (2010) were not found during the sampling. Shishodia et al. (2010) found seven subfamilies with maximum number of species in subfamily Oedipodinae (31\%), followed by subfamily Acridinae (15\%), Eyprepocnemidinae (15\%), Cyrtacanthacridinae (15\%), Oxyinae (8\%), Tropidopolinae (8\%) and Gomphocerinae (8\%). The present study also support the findings of Shishodia et al. (2010) with some changes as the species of subfamily Oedipodinae were reported in maximum percentage followed 
Table 1. Species of family Acrididae found in Haryana with their localities.

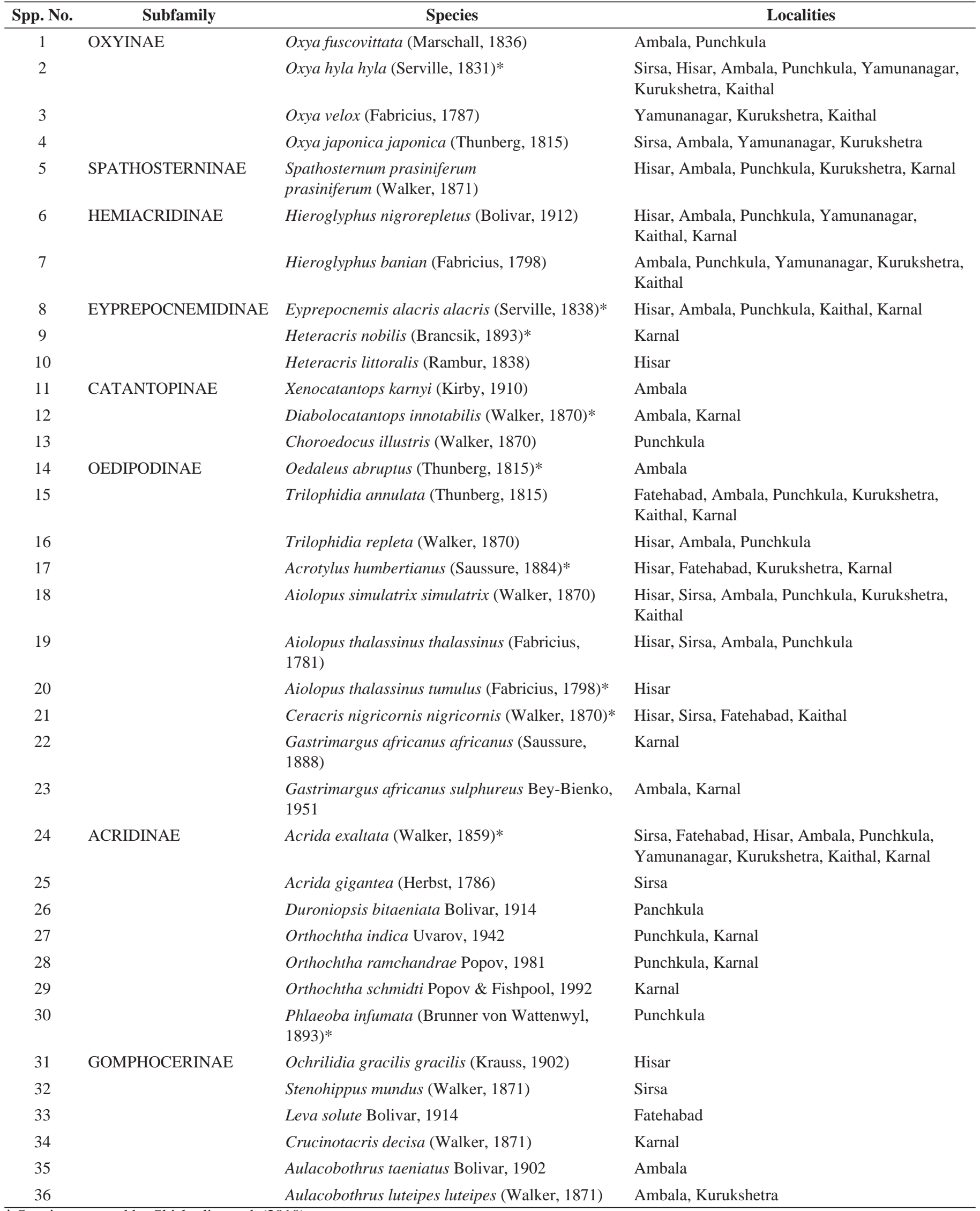

* Species reported by Shishodia et al. (2010). 


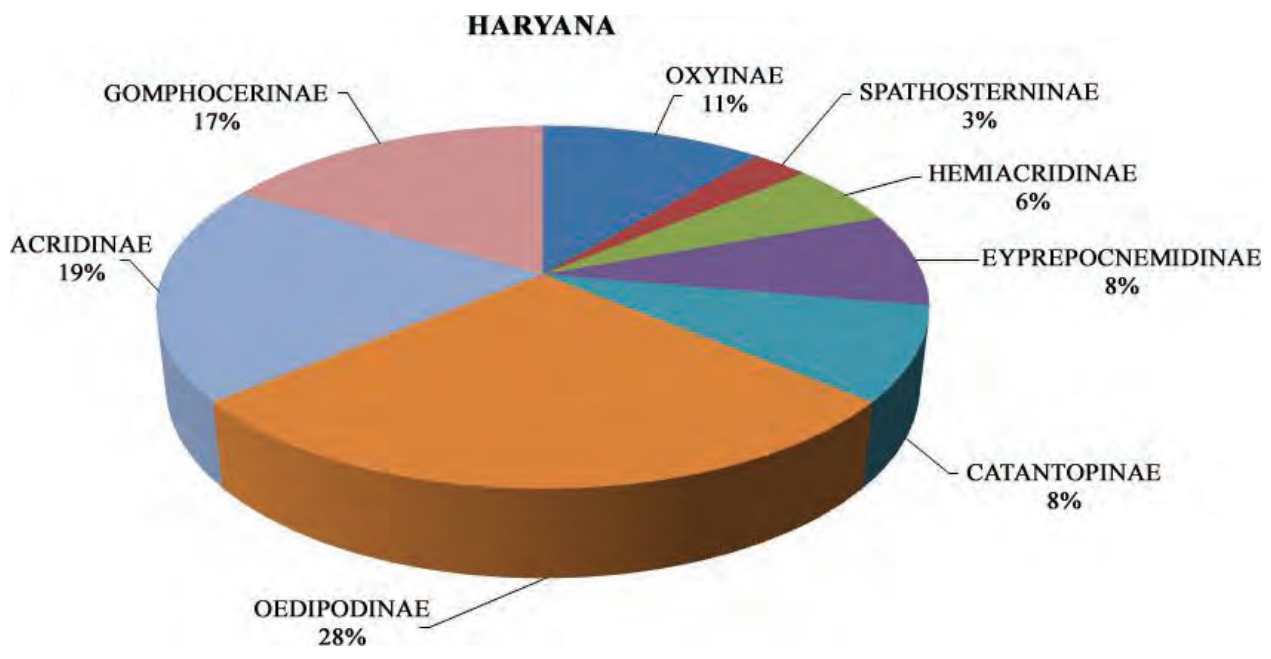

Figure 2. Percentage occurrence of different subfamilies of Acrididae in Haryana, India.

by the subfamily Acridinae. Shishodia et al. (2010) were unable to find members of subfamilies Spathosterninae, Hemiacridinae and Catantopinae. So, the present study is a distinct addition to the Acridid fauna of Haryana.

ACKNOWLEDGEMENTS. We wish to extend our gratitude to Department of Science \& Technology, New Delhi for providing financial assistance during the tenure of a major research project (Ref. No. SR/ SO/AS 32/2008) being carried out on Biosystematics and Biodiversity of Acridoidea (Orthoptera) in North India. Thanks are also due to Prof. Iqbal Parwez, Chairman, Department of Zoology, Aligarh Muslim University, for providing facilities.

\section{LITERATURE CITED}

Bhowmik, H. K. 1985. Outline of distribution with an index-Catalogue of Indian grasshoppers (Orthoptera: Acrididae). Part I. Subfamilies-Acridinae, Truxalinae, Gomphocerinae and Oedipodinae. Records of the Zoological Survey of India, 78: 1-51.

Chandra, K., Gupta, S. K. \& Shishodia, M. S. 2007. A checklist of Orthoptera of Madhya Pradesh and Chhattisgarh. Zoos `Print Journal, 22: 2683-2687.

Chandra, K., Shishodia, M. S. \& Gupta, S. K. 2010. Diversity of Orthoptera (Insecta) in India: State of our Knowledge, pp. 43-80. In: R. K. Gupta (Ed). Advancements in Invertebrate Taxonomy and Biodiversity. Agrobios (India), Jodhpur.

Hazra, A. K., Tandon, S. K., Shishodia, M. S., Dey, A. \& Mandal, S. K. 1993. Insecta: Orthoptera: Acridoidea. Pp. 287-354. In: Director (Ed). Fauna of West Bengal, Part 4. State Fauna Series 3. Zoological Survey of India, Kolkata.

Henry, G. M. 1940. New and little known South Indian Acrididae (Orthoptera). Transactions of the Royal Entomological Society of London. 90: 497-540.

Ingrisch, S., Willemse, F. \& Shishodia, M. S. 2004. New species and interesting records of Acrididae (Orthoptera) from Northeast India. Tijdschriftvoor Entomologie, 147: 289-320.

Kirby, W. F. 1914. The Fauna of British India, including Ceylon and Burma. Taylor and Francis, London.
Kulkarni, P. P. \& Shishodia, M. S. 2004. Insecta: Orthoptera. Pp. 207-225. In: Director (Ed). Fauna of Pench National Park. Conservation Area Series 20. Zoological Survey of India, Kolkata.

Kumar, H. \& Usmani, M. K. 2012a. A Checklist of Acridoidea (Orthoptera) of Punjab, India. Journal of Entomological Research, 36: 173-175.

Kumar, H. \& Usmani, M. K. 2012b. A Checklist of Acrididae (Orthoptera: Acridoidea) of Himachal Pradesh. Advances in Life Sciences, 1: 162-163.

Priya, A. V. \& Narendran, T. C. 2003. A key and a checklist of the genera of short-horned grasshoppers (Orthoptera: Acridoidea) of Kerala. Entomon, 28: 223-230.

Saini, K. \& Mehta, H. S. 2007. An inventory of the Orthoptera insects of Himachal Pradesh. Bionotes, 9: 76-78.

Senthilkumar, N. 2010. Orthopteroids in Kaziranga National Park, Assam, India. Journal of Threatened Taxa, 2: 1227-231.

Shishodia, M. S. 1997. Insecta: Orthoptera, pp. 173-196. In: Director (Ed). Fauna of Delhi. State Fauna Series 6. Zoological Survey of India, Kolkata.

Shishodia, M. S. 1999. Orthoptera fauna of Patalkot, Chhindwara, Madhya Pradesh, India. Records of the Zoological Survey of India, 97: 33-43.

Shishodia, M. S. 2000. Orthoptera (Insecta) fauna of Andaman and Nicobar Islands. Records of the Zoological Survey of India, 98: $1-24$.

Shishodia, M. S. 2008. Insecta: Orthoptera, pp. 45-49. In: Director (Ed). Fauna of Pin Valley National Park. Conservation Area Series 34. Zoological Survey of India, Kolkata.

Shishodia, M. S. \& Dey, A. 2006. Insecta: Orthoptera, pp. 95-110. In: Director (Ed). Fauna of Nagaland. State Fauna Series 12. Zoological Survey of India, Kolkata.

Shishodia, M. S. \& Dey, A. 2007. Insecta: Orthoptera, pp. 187-206. In: Director (Ed). Fauna of Mizoram. State Fauna Series 14. Zoological Survey of India, Kolkata.

Shishodia, M. S. \& Gupta, S. K. 2009. Checklist of Orthoptera (Insecta) of Himachal Pradesh, India. Journal of Threatened Taxa, 1: 569-572.

Shishodia, M. S. \& Mandal, S. K. 1990. New records of Orthoptera (Insecta) from the Nagarjuna sagar tiger reserve forest, Andhra Pradesh, India. Records of the Zoological Survey of India, 87: 65-76. 
Shishodia, M. S. \& Tandon, S. K. 2000. Insecta: Orthoptera, pp. 197230. In: Director (Ed). Fauna of Tripura. State Fauna Series 7. Zoological Survey of India, Kolkata.

Shishodia, M. S., Chandra, K. \& Gupta, S. K. 2010. An annotated checklist of Orthoptera (Insecta) from India. Records of the zoological Survey of India. 314: 1-366.

Shishodia, M. S., Mehta, H. S., Mattu, V. K. \& Thakur, S. K. 2003. Orthoptera (Insecta) from Pong dam wetland, district Kangra, Himachal Pradesh, India. Zoos’ Print Journal. 18: 10471048.

Shrinivasan, C. \& Muralirangan, M. C. 1992. Studies on shorthorned grasshoppers (Acridoidea) of Tamil Nadu Part I: Acridinae, Truxalinae, Gomphocerinae and Locustinae. Hexapoda, 4: 13-26.

Tandon, S. K. \& Shishodia, M. S. 1969. On a collection of Acridoidea (Orthoptera) from the Nagarjuna Sagar Dam Area. Oriental Insects, 3: 265-267.

Tandon, S. K. \& Shishodia, M. S. 1976a. On a collection of Acridoidea (Orthoptera) from Rajasthan, India. Newsletter of Zoological Survey of India, 2: 7-11.
Tandon, S. K. \& Shishodia, M. S. 1976b. Acridoidea (Insecta: Orthoptera) collected along the bank of river Tawi (J\&K) India. Newsletter of Zoological Survey of India, 2: 58-61.

Tandon, S. K. \& Shishodia, M. S. 1976c. On a collection of Orthoptera (Insecta) from the Kanha National Park, Madhya Pradesh, India. Newsletter of Zoological Survey of India, 2: 269-271.

Tandon, S. K. \& Shishodia, M. S. 1977. The Acridoidea (Insecta: Orthoptera) of Goa. Records of the Zoological Survey of India, 72: 295-307.

Thakur, S. K., Shishodia, M. S., Mehta, H. S. \& Mattu, V. K. 2004. Orthoptern diversity of Roper Wetland Punjab, India. Zoos` Print journal, 19: 1697.

Usmani, M. K. \& Shafee, S. A. 1990. Classification of Indian Acrididae (Orthoptera: Acridoidea). Indian Journal of Systematic Entomology, 7: 89-102.

Usmani, M. K., Khan, M. I. \& Kumar, H. 2010. Studies on Acridoidea (Orthoptera) of Western Uttar Pradesh. Biosystematica, 4: 39-58.

Uvarov, B. P. 1927. Distributional records of Indian Acrididae. Records of the Indian Museum, 29: 233-239. 